Matematikai Közlemények

IV. kötet, 2017

doi:10.20312/dim.2017.06

\title{
Gazdasági változások regressziós vizsgálata
}

\author{
Csanády Viktória \\ SOE Matematikai Intézet \\ csanady.viktoria@uni-sopron.hu
}

\begin{abstract}
ÖSSZEFOGLALÓ. A gazdasági folyamatok elemzése során számtalan esetben támaszkodnak adatsorokra, termelési vagy fogyasztási értékek időbeni alakulása alapján. A folyamatok vizsgálatára a trendszámítást alkalmazzák, már közismert modellek felhasználása révén. Az alábbiakban egy speciális modell illesztésére kerül sor, illetve annak kielemzésére.
\end{abstract}

ABSTRACT. Examining economic processes, the analysis is often based on time series data, considering the timely evolution of production- or consumption values. Trend estimation is applied for examining the tendencies using well-known models. In the following we are going to fit a special model to data and analyse it.

\section{Bevezetés}

A gazdasági folyamatok vizsgálata során számtalan esetben alkalmaznak trendszámítást, ami az illesztett modell alapján többé-kevésbé követi a folyamatot és elöre jelzést is szolgál. Az esetek többségében az alkalmazott modellek közismertek, gyakran használt függvények. Több különböző gazdasági adat összevetése viszont nehézkes velük akkor, ha a dimenziók nagyságrendje különböző. Így esett a választás egy új modell alkalmazására. A vizsgálat az 1960 és 2015 évek között eltelt 56 év gazdasági változásának elemzéséhez 12 adatsort használ, melyek kiválasztása véletlenszerüen történt a Központi Statisztikai Hivatal adatbázisából. A vizsgált adatsorok az alábbiak:

1.) Egy főre jutó évi burgonya kg mennyiség változása.

2.) Családi pótlékkal rendelkezők éves létszámának változása.

3.) Gyakorlatilag aktív népesség ezer fős éves létszámának változása.

4.) Földgáz millió köbméteres értékủ éves igénybevételének változása.

5.) Tizezer főre jutó kórházi ágyak éves számának változása.

6.) Nyugdíjas létszám éves változása.

7.) Óvodások ezer fôs éves létszámának változása.

8.) Pamutszövet millió négyzetméteres éves felhasználási mennyiségének változása.

9.) Millió liter egységben rendelkezésre álló sör éves mennyiségének változása.

10.) Millió számú vezetékes telefon hívások éves számának változása.

11.) Egy före jutó évi tojás darabszám éves változása.

12.) Helyi évi személyszállítási utasszám indexének éves változása.

$\mathrm{Az}$ adatsorokra történt görbeillesztéshez egy olyan modell használata bizonyult megfelelőnek, amely a rugalmasság és az egyszerü kezdőérték megválasztás miatt könnyen 
kezelhető. A függvény összetett szerkezetü, zárt értelmezési tartományú. Ezen kritériumok miatt a választott modell két eltolt helyzetü Awrami függvény szuperponáltja.

A vizsgált adathalmaz és az alkalmazott modell a következő:

$\mathrm{Az}$ alábbiakban bemutatásra kerül a vizsgált adatsor egy részlete. A táblázat első oszlopában az évek, első sorában a sorszámozott vizsgálati adatsorok kerültek feltüntetésre az előzőekben történt felsorolás szerint.

\begin{tabular}{||c||c|c|c|c|c|c|c|c|c|c|c|c||}
\hline \hline Év & 1 & 2 & 3 & 4 & 5 & 6 & 7 & 8 & 9 & 10 & 11 & 12 \\
\hline \hline 1960 & 97,6 & 577 & 4735 & 342 & 72,3 & 636 & 184 & 247 & 356 & 538 & 160 & 100 \\
\hline 1961 & 95,0 & 593 & 4626 & 327 & 73,0 & 796 & 172 & 264 & 378 & 558 & 161 & 104 \\
\hline 1962 & 94,1 & 609 & 4544 & 340 & 74,8 & 912 & 178 & 281 & 383 & 572 & 159 & 107 \\
\hline 1963 & 91,7 & 614 & 4569 & 611 & 75,7 & 983 & 184 & 292 & 408 & 596 & 163 & 108 \\
\hline 1964 & 87,8 & 612 & 4653 & 784 & 76,6 & 1046 & 187 & 314 & 423 & 606 & 180 & 113 \\
\hline
\end{tabular}

\begin{tabular}{||c||c|c|c|c|c|c|c|c|c|c|c|c||}
\hline 2010 & 60,5 & 1224 & 4177 & 1849 & 71,3 & 2980 & 338 & 3 & 616 & 1678 & 235 & 108 \\
\hline 2011 & 63,5 & 1191 & 4192 & 1734 & 71,5 & 2921 & 341 & 2 & 645 & 1599 & 217 & 108 \\
\hline 2012 & 62,3 & 1168 & 4245 & 5564 & 69,5 & 2919 & 340 & 2 & 639 & 1426 & 215 & 106 \\
\hline 2013 & 58,6 & 1150 & 4296 & 5404 & 70,0 & 2869 & - & 12 & 600 & 1344 & 214 & 106 \\
\hline 2014 & 53,0 & 1114 & 4385 & 5134 & 69,8 & 2801 & - & 8 & 595 & 1188 & - & 111 \\
\hline 2015 & - & 1108 & 4464 & 4689 & 69,8 & 2727 & - & 11 & 582 & 1061 & - & 113 \\
\hline 2016 & - & - & 4538 & 4340 & - & - & - & - & - & - & - & - \\
\hline
\end{tabular}

1. táblázat. Adathalmaz

\section{Az allkalmazott regressziós modell}

- hagyományos matematikai alakja:

$$
y=b_{8}-b_{7} \cdot e^{\left(-1 \cdot\left(b_{6} \cdot\left(x-b_{5}\right)\right)^{b_{4}}\right)}-b_{3} \cdot e^{\left(-1 \cdot\left(-1 \cdot b_{2} \cdot\left(x-b_{1}\right)\right)^{b_{0}}\right)}
$$

- a számítógépes alak:

$$
\operatorname{var} 2=\mathrm{b} 8-\mathrm{b} 7 * \exp \left(-1 *(\mathrm{~b} 6 *(\operatorname{var} 1-1 * \mathrm{~b} 5))^{\wedge} \mathrm{b} 4\right)-\mathrm{b} 3 * \exp \left(-1 *(-1 * \mathrm{~b} 2 *(\operatorname{var} 1-1 * \mathrm{~b} 1))^{\wedge} \mathrm{b} 0\right) .
$$

A feltüntetett függvény minden olyan adatsor regressziós vizsgálatára alkalmazható, mely adatsor var2 értéke az értelmezési tartományon belül maximum vagy minimum értékkel rendelkezik. Az értelmezési tartomány pedig eleget tesz $b 5<$ var $1<\mathrm{b} 1$ feltételnek.

Kezdőértékek meghatározása az adatsor értékei alapján a következő módon történik:

b8 = a maximális vagy minimális var2 érték,

b7 = a maximális vagy minimális var2 érték mínusz a kezdő var2 érték,

b6 = a var1 nagyságrend reciproka, az esetek többségében $0,1(0,05)$,

b5 = a var1 kezdőértéke, vagy annál relatív kisebb,

b4 = az esetek többségében 3 (5),

b3 = a maximális vagy minimális var2 érték mínusz a végső var2 érték,

b2 = a var1 nagyságrend reciproka, az esetek többségében $0,1(0,05)$,

b1 = a var1 végsőértéke, vagy annál relatív nagyobb,

b0 = az esetek többségében 3 (5). 


\section{A modell levezetése}

A kérdéses függvény egy normál helyzetü transzformált és egy y-tengelyre tükrözött megfelelően transzformált Awrami függvény összegéből került kialakításra, zárt értelmezési tartomány feltételével.

A kiindulási matematikai alak:

$$
y=a \cdot\left(1-\frac{1}{e^{\left((b \cdot(x-c))^{d}\right)}}\right)+f \cdot\left(1-\frac{1}{e^{\left((-g \cdot(x-h))^{i}\right)}}\right)+k,
$$

ahol az értelmezési tartomány $\mathrm{c}<\mathrm{X}<\mathrm{h}$ (természetesen d és i nem páros egész).

Átalakítási lépések:

1. $y=a-\frac{a}{e^{\left((b \cdot(x-c))^{d}\right)}}+f-\frac{f}{e^{\left((-g \cdot(x-h))^{i}\right)}}+k$

2. $y=a+f+k-\frac{a}{e^{\left((b \cdot(x-c))^{d}\right)}}-\frac{f}{e^{\left((-g \cdot(x-h))^{i}\right)}}$

3. $a+f+k=r$

4. $y=r-\frac{a}{e^{\left((b \cdot(x-c))^{d}\right)}}-\frac{f}{e^{\left((-g \cdot(x-h))^{i}\right)}}$

5. $r=b_{8}, a=b_{7}, b=b_{6}, c=b_{5}, d=b_{4}, f=b_{3}, g=b_{2}, h=b_{1}, i=b_{0}$

6. $y=b_{8}-\frac{b_{7}}{e^{\left(\left(b_{6} \cdot\left(x-b_{5}\right)\right)^{b_{4}}\right)}}-\frac{b_{3}}{e^{\left(\left(-b_{2} \cdot\left(x-b_{1}\right)\right)^{b_{0}}\right)}}$

7. $y=b_{8}-b_{7} \cdot e^{\left(-1 \cdot\left(b_{6} \cdot\left(x-b_{5}\right)\right)^{b_{4}}\right)}-b_{3} \cdot e^{\left(-1 \cdot\left(-1 \cdot b_{2} \cdot\left(x-b_{1}\right)\right)^{b_{0}}\right)}$.

\section{A fenti modellből pedig a számítógépi allak}

$\operatorname{var} 2=\mathrm{b} 8-\mathrm{b} 7 * \exp \left(-1 *(\mathrm{~b} 6 *(\operatorname{var} 1-1 * \mathrm{~b} 5))^{\wedge} \mathrm{b} 4\right)-\mathrm{b} 3 * \exp \left(-1 *(-1 * \mathrm{~b} 2 *(\operatorname{var} 1-1 * \mathrm{~b} 1))^{\wedge} \mathrm{b} 0\right)$.

$\mathrm{Az}$ alkalmazott regressziós függvénnyel kapcsolatban fontos további megjegyzések a következők:

- Ha a vizsgált adatsor var1(kezdő) és var1(végső) értékétől az illesztés során kapott b5 és b1 érték jelentős mértékben nem tér el, akkor nemcsak a görbéről kaphatunk pontos adatokat, hanem a paraméterek is közvetlen értelmezhetők a következők szerint: $\mathrm{b} 8=\operatorname{var} 2(\max )$,

- b8-b7=var2(kezdő), b8-b3=var2(végső) érték. A függvény illesztésének feltétele, hogy az adott adatsor legfeljebb egy maximum vagy minimum hellyel, és legfeljebb két inflexiós hellyel rendelkezzen.

\section{Számított eredmények, kiértékelés}

\subsection{A regressziós eljárással nyert eredmények}

Az illesztés során kapott eredményeket, az alábbiak mutatják az adatsorok számozási sorrendjében. 


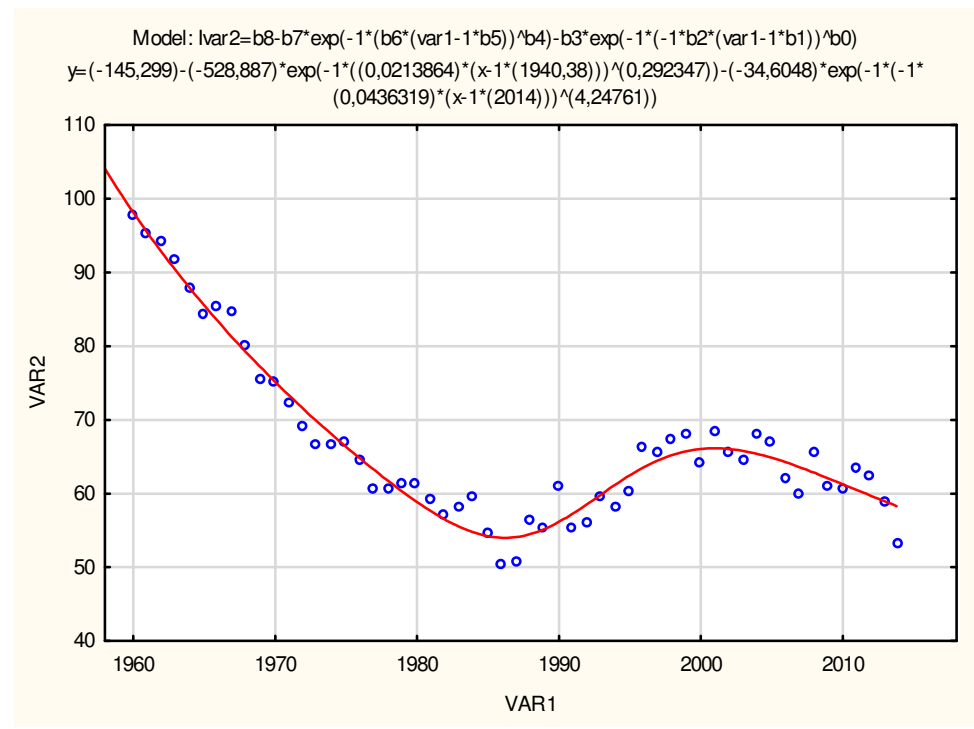

1. ábra. 1Burgonya

\begin{tabular}{|c|c|c|c|c|c|c|c|c|c|}
\hline \multirow[b]{2}{*}{$N=55$} & \multicolumn{9}{|c|}{ 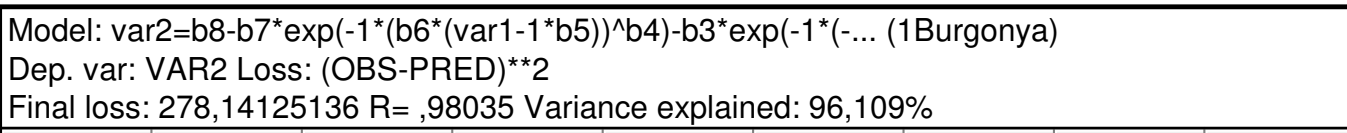 } \\
\hline & \begin{tabular}{|l|} 
b8 \\
\end{tabular} & b7 & b6 & b5 & b4 & b3 & b2 & b1 & b0 \\
\hline Estimate & $-145,29$ & $-528,88$ & 0,02138 & 1940,37 & 0,29234 & $-34,604$ & 0,04363 & 2014,00 & 4,2476 \\
\hline
\end{tabular}

2. táblázat. 1Burgonya

Model: Ivar2=b8-b7*exp $\left(-1^{*}\left(b 6^{*}\left(\operatorname{var} 1-1^{*} \mathrm{~b} 5\right)\right)^{\wedge} \mathrm{b} 4\right)-\mathrm{b} 3^{*} \exp \left(-1^{*}\left(-1^{*} \mathrm{~b} 2^{*}\left(\operatorname{var} 1-1^{*} \mathrm{~b} 1\right)\right)^{\wedge} \mathrm{b} 0\right)$

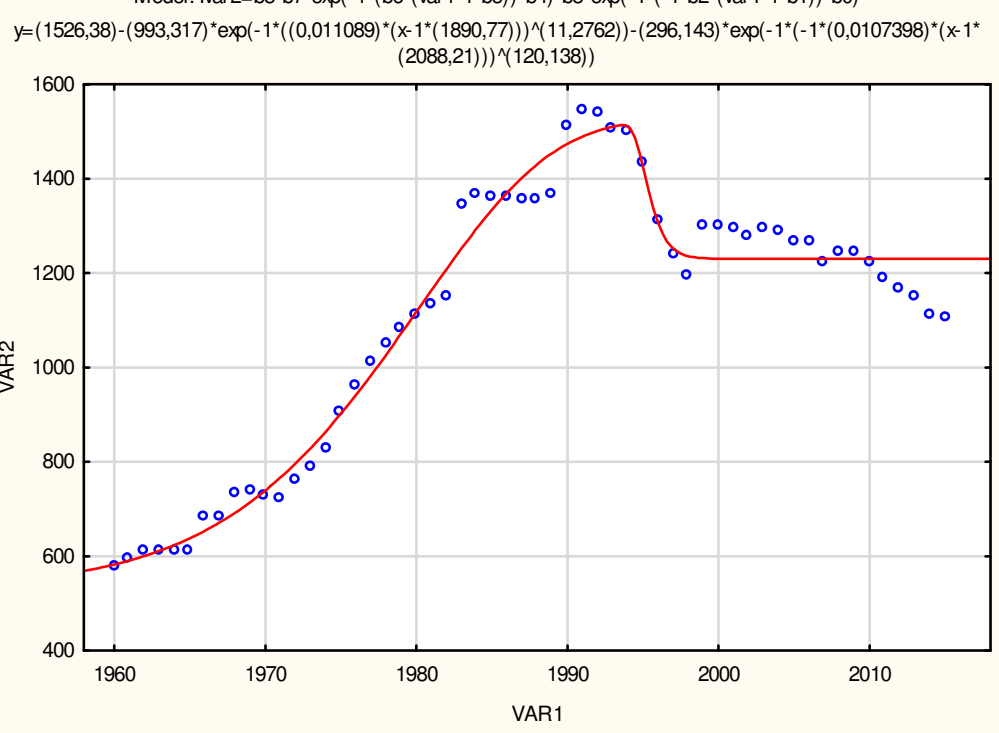

2. ábra. 2Csalpót

\begin{tabular}{|c|c|c|c|c|c|c|c|c|c|}
\hline \multirow[b]{2}{*}{$N=56$} & \multicolumn{9}{|c|}{ 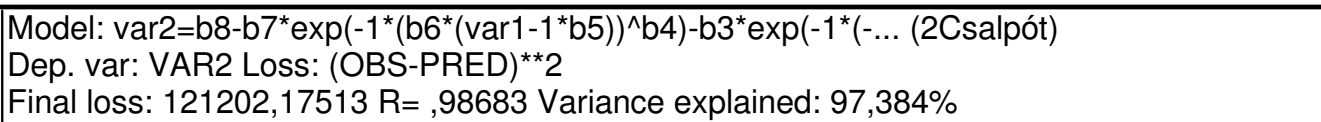 } \\
\hline & b8 & b7 & b6 & b5 & b4 & b3 & b2 & b1 & b0 \\
\hline Estimate & 1526,38 & 993,316 & 0,01108 & 1890,77 & 11,2761 & 296,143 & 0,01074 & $2088,2 C$ & 120,137 \\
\hline
\end{tabular}

3. táblázat. 2Csalpót 


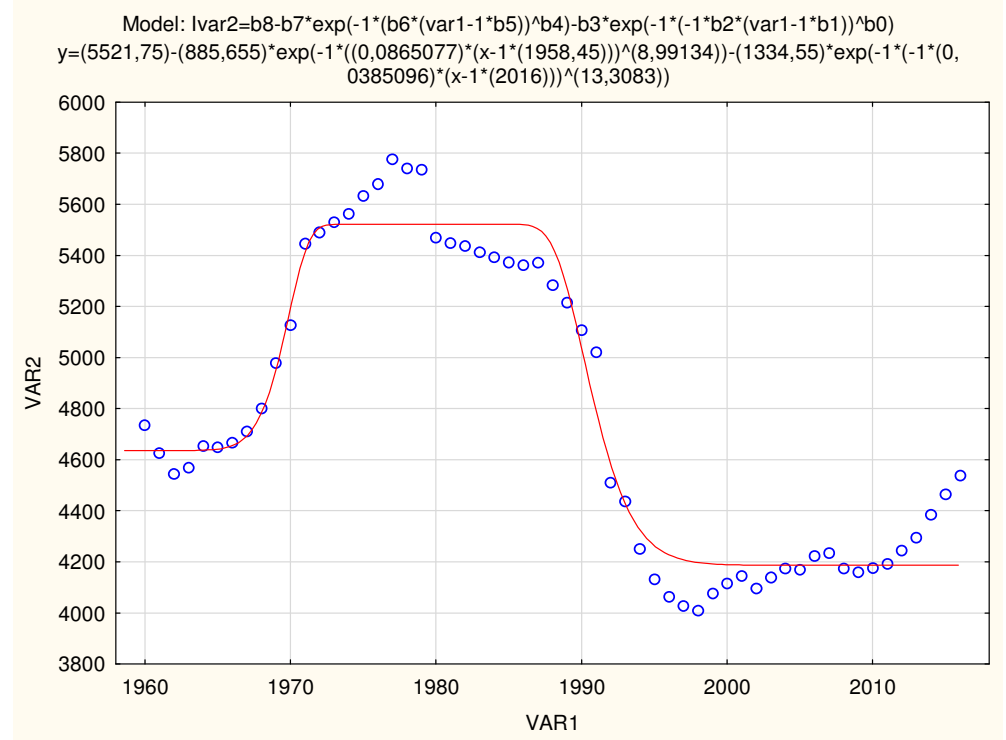

3. ábra. 3Dolgozó

\begin{tabular}{|c|c|c|c|c|c|c|c|c|c|}
\hline \multirow[b]{2}{*}{$\mathrm{N}=57$} & \multicolumn{9}{|c|}{ 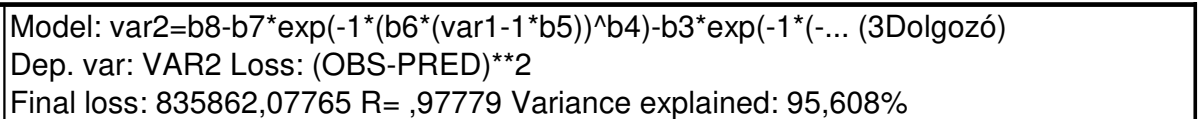 } \\
\hline & b8 & b7 & b6 & b5 & b4 & b3 & $\mathrm{b} 2$ & b1 & b0 \\
\hline Estimate & 5521,7 & 885,65 & 0,0865 & 1958,4 & 8,9913 & 1334,5 & 0,0385 & 2016,0 & 13,308: \\
\hline
\end{tabular}

4. táblázat. 3Dolgozó

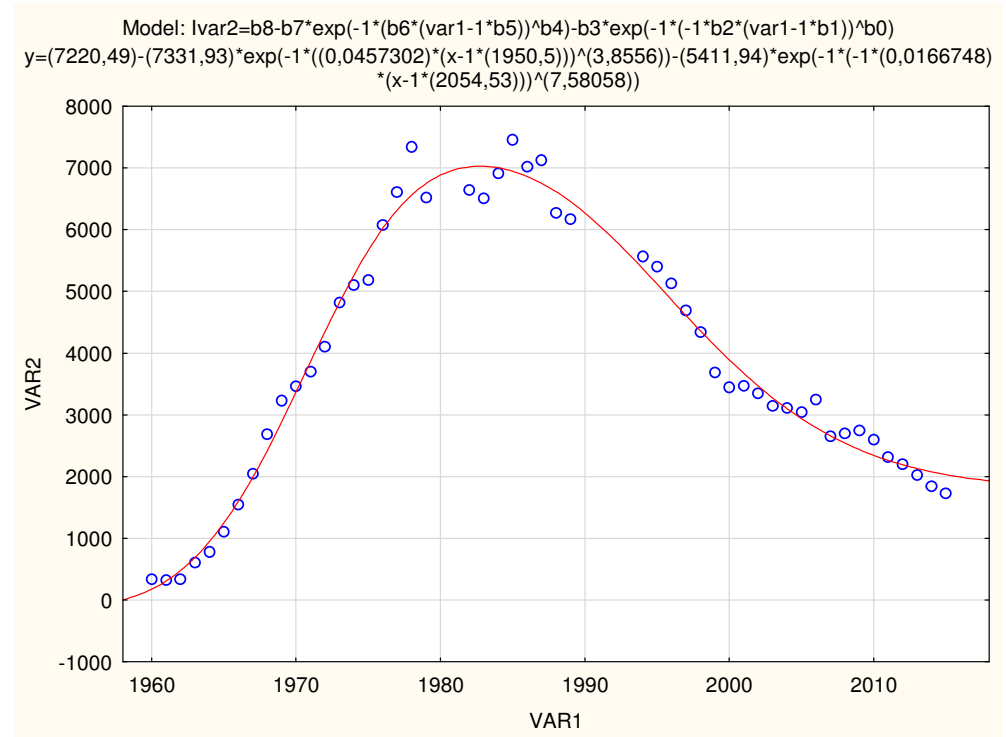

4. ábra. 4Földgáz

\begin{tabular}{|c|c|c|c|c|c|c|c|c|c|}
\hline \multirow[b]{2}{*}{$\mathrm{N}=50$} & \multicolumn{9}{|c|}{$\begin{array}{l}\text { Model: var2=b8-b7*exp }\left(-1^{*}\left(b 6^{*}\left(\operatorname{var} 1-1^{*} \mathrm{~b} 5\right)\right)^{\wedge} \mathrm{b} 4\right)-\mathrm{b} 3^{*} \exp \left(-1^{*}(-\ldots \text { (4Földgáz) }\right. \\
\text { Dep. var: VAR2 Loss: (OBS-PRED) }{ }^{\star *} 2 \\
\text { Final loss: } 3659883,1679 \mathrm{R}=, 99139 \text { Variance explained: } 98,285 \%\end{array}$} \\
\hline & b8 & b7 & b6 & b5 & b4 & b3 & b2 & b1 & b0 \\
\hline Estimate & $7220,4 \varepsilon$ & $7331,9:$ & $0,0457 i$ & $1950,5($ & $3,8556($ & $5411,9:$ & 0,0166 & $2054,5:$ & 7,5805 \\
\hline
\end{tabular}

5. táblázat. 4 Földgáz 
Model: Ivar2=b8-b7* $\exp \left(-1^{*}\left(\mathrm{~b} 6^{*}\left(\operatorname{var} 11^{*} \mathrm{~b} 5\right)\right)^{\wedge} \mathrm{b} 4\right)-\mathrm{b} 3^{*} \exp \left(-1^{*}\left(-1^{*} \mathrm{~b} 2^{*}\left(\operatorname{var} 11^{*} \mathrm{~b} 1\right)\right)^{\wedge} \mathrm{b} 0\right)$ $y=(111,135)-(41,707)^{*} \exp \left(-1^{*}\left((0,0106063)^{*}\left(x-1^{*}(1890,51)\right)\right)^{\wedge}(6,53648)\right)-(41,1747)^{*} \exp \left(-1^{*}\left(-1^{*}(0,0141494\right.\right.$

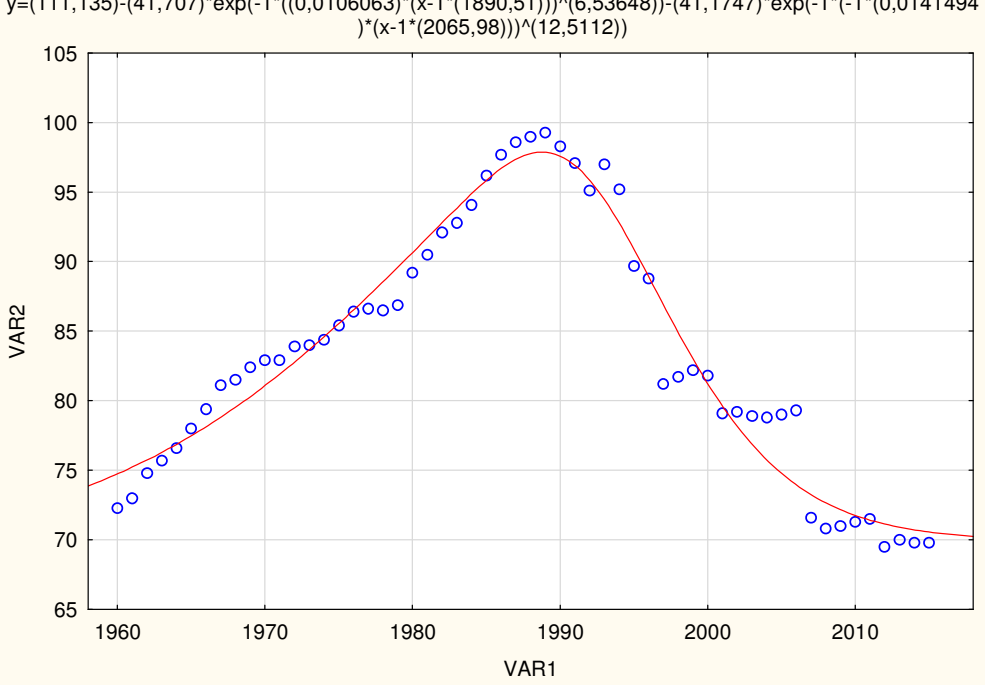

5. ábra. 5Kórágyak

\begin{tabular}{|c|c|c|c|c|c|c|c|c|c|}
\hline \multirow[b]{2}{*}{$\mathrm{N}=56$} & \multicolumn{9}{|c|}{$\begin{array}{l}\left.\text { Model: var2=b8-b7*exp }\left(-1^{*}\left(\mathrm{~b} 6^{*}\left(\mathrm{var} 1-1^{*} \mathrm{~b} 5\right)\right)\right)^{\wedge} \mathrm{b} 4\right)-\mathrm{b} 3^{*} \exp \left(-1^{*}(-\ldots \text { (5Kórágyak) }\right. \\
\text { Dep. var: VAR2 Loss: }(\text { OBS-PRED })^{\star *} 2 \\
\text { Final loss: } 189,96074534 \mathrm{R}=, 97876 \text { Variance explained: } 95,796 \%\end{array}$} \\
\hline & \begin{tabular}{|l|}
$\mathrm{b} 8$ \\
\end{tabular} & b7 & b6 & b5 & b4 & b3 & b2 & b1 & b0 \\
\hline Estimate & 111,13 & $41,706 !$ & 0,0106 & 1890,51 & $6,5364 i$ & $41,174^{\circ}$ & 0,0141 ، & 2065,9 & 12,511 \\
\hline
\end{tabular}

6. táblázat. 5Kórágyak

Model: Ivar2=b8-b7*exp(-1*(b6*(var1-1*b5) $\left.)^{\wedge} \mathrm{b} 4\right)-\mathrm{b} 3^{*} \exp \left(-1^{*}\left(-1^{*} \mathrm{~b} 2^{*}\left(\operatorname{var} 1-1^{*} \mathrm{~b} 1\right)\right)^{\wedge} \mathrm{b} 0\right)$ $y=(5836,93)-(5990,69)^{*} \exp \left(-1^{*}\left((0,0123458)^{*}\left(x-1^{*}(1920,5)\right)\right)^{\wedge}(2,44711)\right)-(78698,9)^{*} \exp \left(-1^{*}\left(-1^{*}(0,0451668\right.\right.$

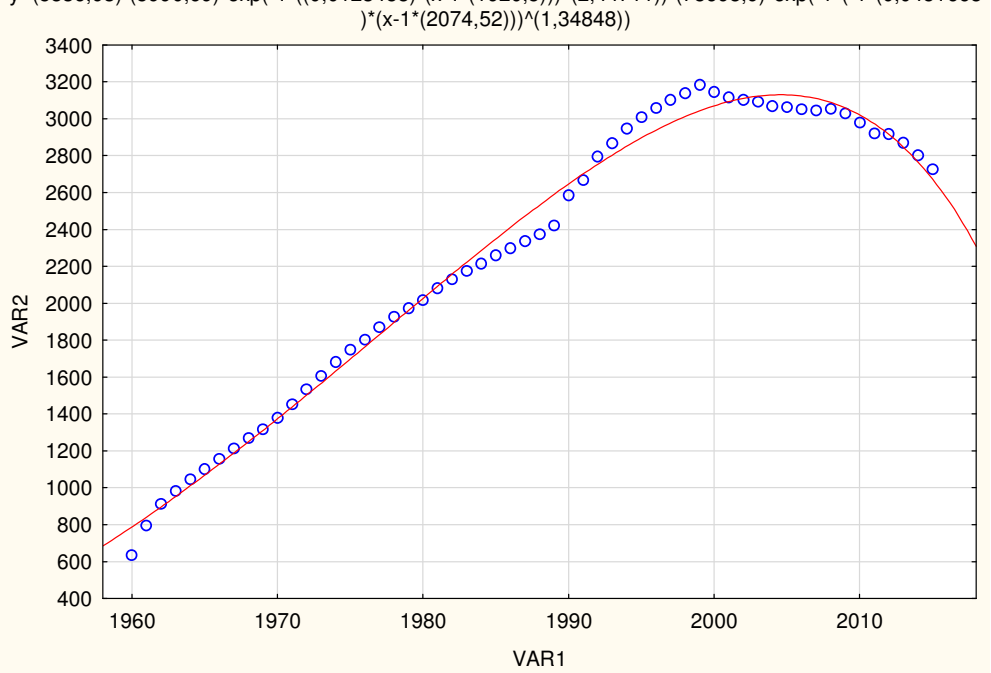

6. ábra. 6Nyugdijas

\begin{tabular}{|c|c|c|c|c|c|c|c|c|c|}
\hline \multirow[b]{2}{*}{$\mathrm{N}=56$} & \multicolumn{9}{|c|}{$\begin{array}{l}\text { Model: var2=b8-b7*exp }\left(-1^{\star}\left(\mathrm{b} 6^{*}\left(\mathrm{var} 1-1^{*} \mathrm{~b} 5\right)\right)^{\wedge} \mathrm{b} 4\right)-\mathrm{b} 3^{*} \exp \left(-1^{*}(-\ldots \text { (6Nyugdíjas })\right. \\
\text { Dep. var: VAR2 Loss: (OBS-PRED)*2 } \\
\text { Final loss: } 277651,61936 \mathrm{R}=, 99576 \text { Variance explained: } 99,154 \%\end{array}$} \\
\hline & b8 & b7 & b6 & b5 & b4 & b3 & b2 & b1 & b0 \\
\hline Estimat $\epsilon$ & 5836,9 & 5990,6 & 0,0123 & 1920,5 & 2,4471 & 78698, & 0,0451 & 2074,5 & 1,3484 \\
\hline
\end{tabular}

7. táblázat. 6Nyugdijas 
Model: Ivar2=b8-b7* $\left.\exp \left(-1^{*}\left(\mathrm{~b} 6^{*}\left(\operatorname{var} 1-1^{*} \mathrm{~b} 5\right)\right)^{\wedge} \mathrm{b} 4\right)-\mathrm{b} 3^{*} \exp \left(-1^{*}\left(-1^{*} \mathrm{~b} 2^{*}\left(\operatorname{var} 1-1^{*} \mathrm{~b} 1\right)\right)\right)^{\wedge} \mathrm{b} 0\right)$

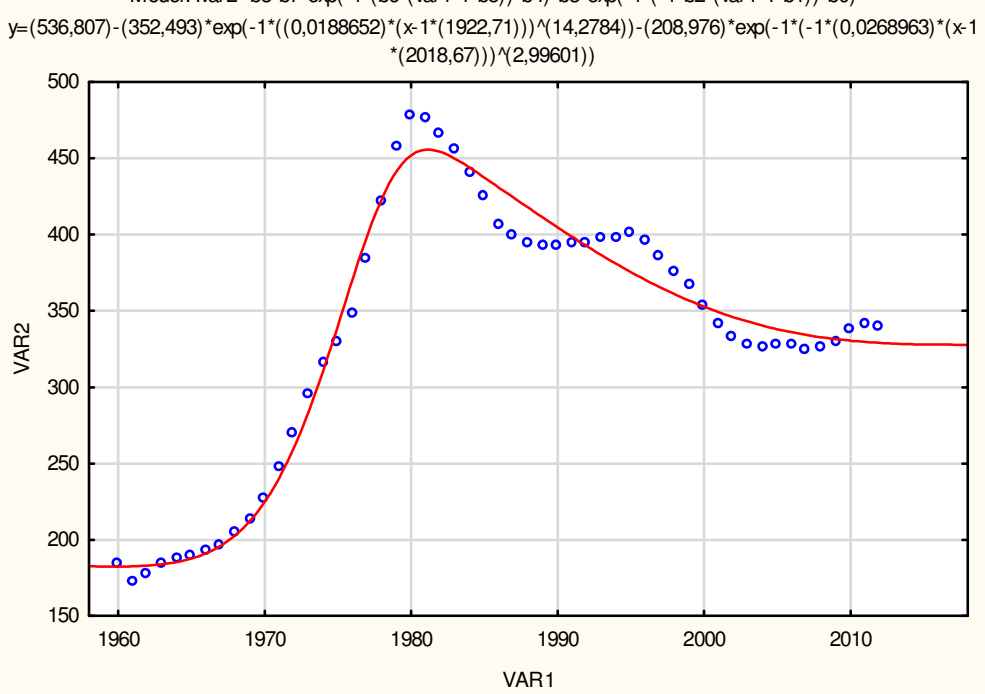

7. ábra. 7Ovodások

\begin{tabular}{|c|c|c|c|c|c|c|c|c|c|}
\hline \multirow[b]{2}{*}{$N=53$} & \multicolumn{9}{|c|}{ 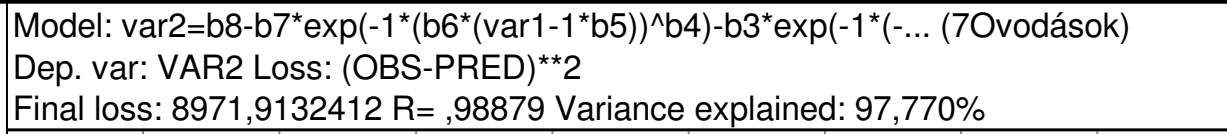 } \\
\hline & b8 & b7 & b6 & b5 & b4 & b3 & b2 & b1 & b0 \\
\hline Estimate & 536,80 & 352,49 & 0,0188 & 1922,7 & 14,278 & 208,97 & 0,0268 & 2018,6 & 2,9960 \\
\hline
\end{tabular}

8. táblázat. 70vodások

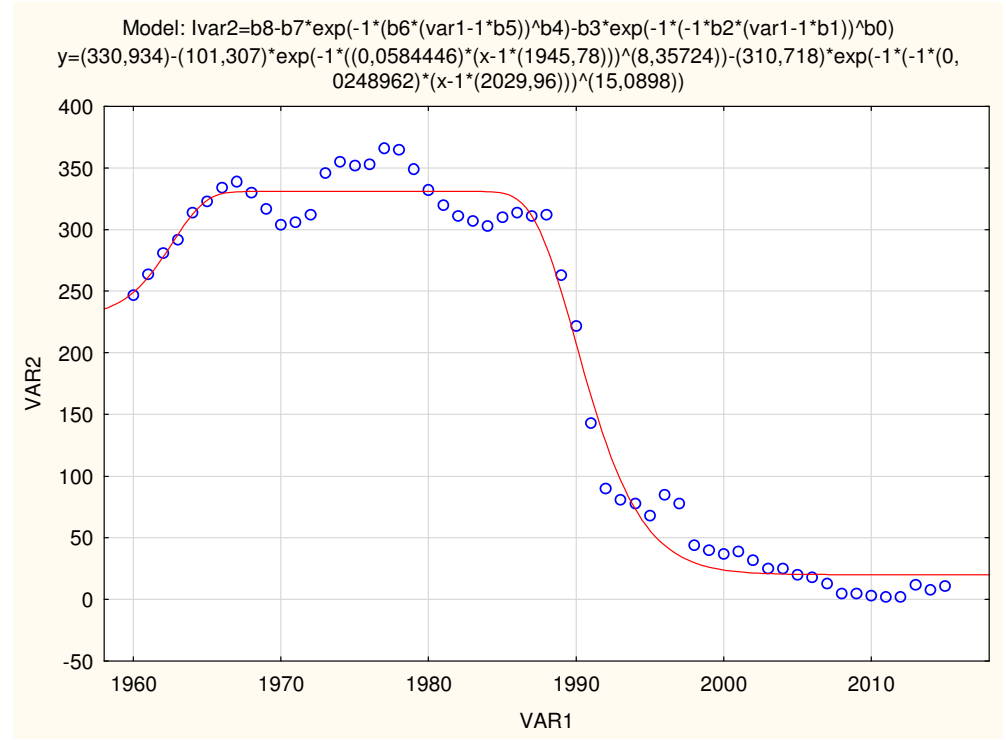

8. ábra. 8Pamutsz

\begin{tabular}{|c|c|c|c|c|c|c|c|c|c|}
\hline \multirow[b]{2}{*}{$N=56$} & \multicolumn{9}{|c|}{$\begin{array}{l}\text { Model: var2=b8-b7*exp }\left(-1^{\star}\left(b 6^{\star}\left(\operatorname{var} 1-1^{\star} \mathrm{b} 5\right)\right)^{\wedge} \mathrm{b} 4\right)-\mathrm{b} 3^{\star} \exp \left(-1^{\star}(-\ldots \text { (8Pamutsz })\right. \\
\text { Dep. var: VAR2 Loss: (OBS-PRED })^{\star \star} 2 \\
\text { Final loss: } 18535,762035 \mathrm{R}=, 99170 \text { Variance explained: } 98,346 \%\end{array}$} \\
\hline & b8 & b7 & b6 & b5 & b4 & b3 & b2 & b1 & $\mathrm{b} 0$ \\
\hline Estimate & 330,93 & 101,30 & 0,0584 & 1945,7 & 8,3572 & 310,71 & 0,0248 & 2029,9 & 15,089 \\
\hline
\end{tabular}

9. táblázat. 8Pamutsz 


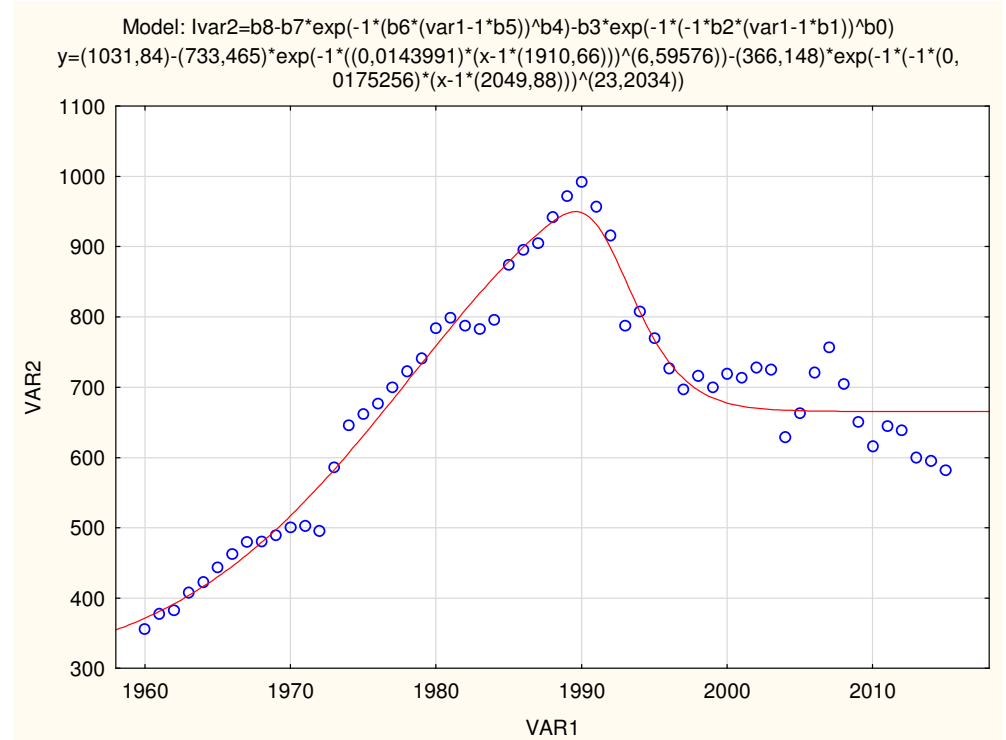

9. ábra. 9Sör

\begin{tabular}{|c|c|c|c|c|c|c|c|c|c|}
\hline \multirow[b]{2}{*}{$\mathrm{N}=56$} & \multicolumn{9}{|c|}{ 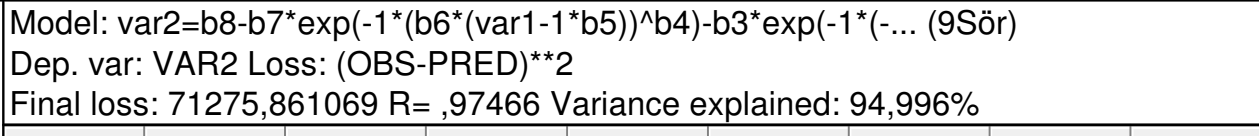 } \\
\hline & \begin{tabular}{|l|} 
b8 \\
\end{tabular} & b7 & b6 & b5 & b4 & b3 & b2 & b1 & b0 \\
\hline Estimate & 1031,8 & 733,46 & 0,0143 & 1910,6 & 6,5957 & 366,14 & 0,0175 & 2049,8 & 23,203 \\
\hline
\end{tabular}

10. táblázat. 9Sör

Model: Ivar2=b8-b7* $\exp \left(-1^{*}\left(\mathrm{~b} 6^{*}\left(\operatorname{var} 1-1^{*} \mathrm{~b} 5\right)\right)^{\wedge} \mathrm{b} 4\right)-\mathrm{b} 3^{*} \exp \left(-1^{*}\left(-1^{*} \mathrm{~b} 2^{*}\left(\operatorname{var} 1-1^{*} \mathrm{~b} 1\right)\right)^{\wedge} \mathrm{b} 0\right)$

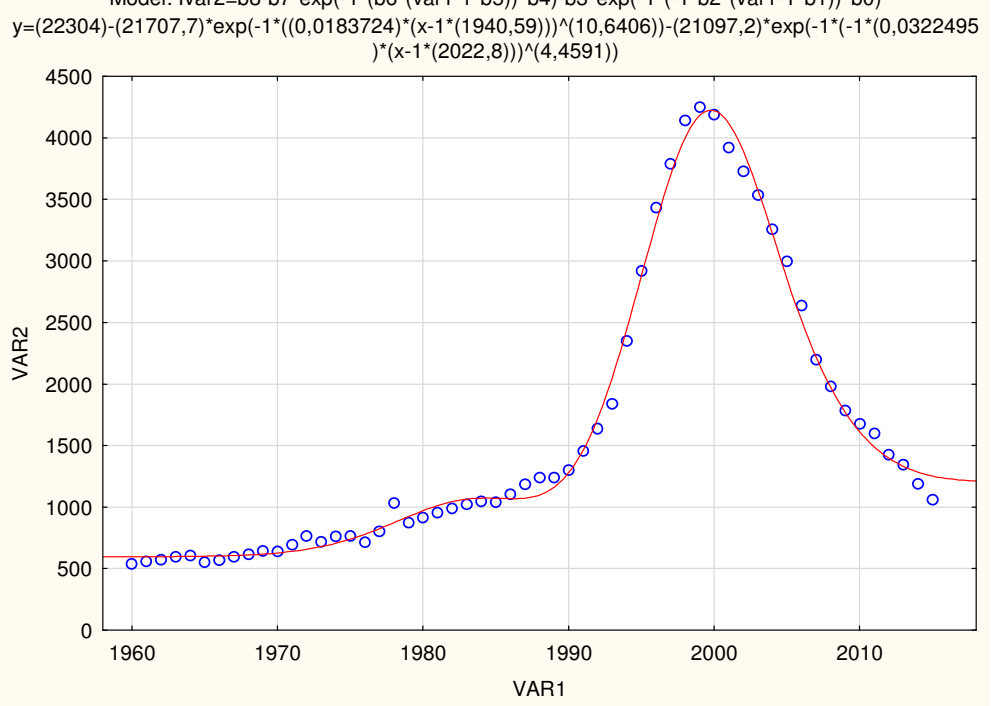

10. ábra. 10Telhívás

\begin{tabular}{|c|c|c|c|c|c|c|c|c|c|}
\hline \multirow[b]{2}{*}{$\mathrm{N}=56$} & \multicolumn{9}{|c|}{$\begin{array}{l}\text { Model: var2=b8-b7* } \exp \left(-1^{*}\left(b 6^{*}\left(\operatorname{var} 1-1^{*} \mathrm{~b} 5\right)\right)^{\wedge} \mathrm{b} 4\right)-\mathrm{b} 3^{*} \exp \left(-1^{*}\left(-\ldots{ }^{(10 T e l h i v a ́ s)}\right.\right. \\
\text { Dep. var: VAR2 Loss: }(\text { OBS-PRED })^{\star *} 2 \\
\text { Final loss: } 400101,55114 \mathrm{R}=, 99720 \text { Variance explained: } 99,440 \%\end{array}$} \\
\hline & \begin{tabular}{|l|} 
b8 \\
\end{tabular} & b7 & b6 & b5 & b4 & b3 & b2 & b1 & $\mathrm{b} 0$ \\
\hline Estimate & 22304,1 & 21707,1 & 0,0183 & 1940,5 & 10,6401 & 21097,؛ & 0,0322 & 2022,81 & 4,4591 \\
\hline
\end{tabular}

11. táblázat. 10Telhívás 
Model: Ivar2=b8-b7* $\left.\exp \left(-1^{*}\left(\mathrm{~b} 6^{*}\left(\operatorname{var} 1-1^{*} \mathrm{~b} 5\right)\right)\right)^{\wedge} \mathrm{b} 4\right)-\mathrm{b} 3^{*} \exp \left(-1^{*}\left(-1^{*} \mathrm{~b} 2^{*}\left(\operatorname{var} 1-1^{*} \mathrm{~b} 1\right)\right)^{\wedge} \mathrm{b} 0\right)$ $y=(648,331)-(379,92)^{*} \exp \left(-1^{*}\left((0,0185044)^{*}\left(x-1^{*}(1919,65)\right)\right)^{\wedge}(5,07654)\right)-(682,147)^{*} \exp \left(-1^{*}\left(-1^{*}(0,014745)\right.\right.$

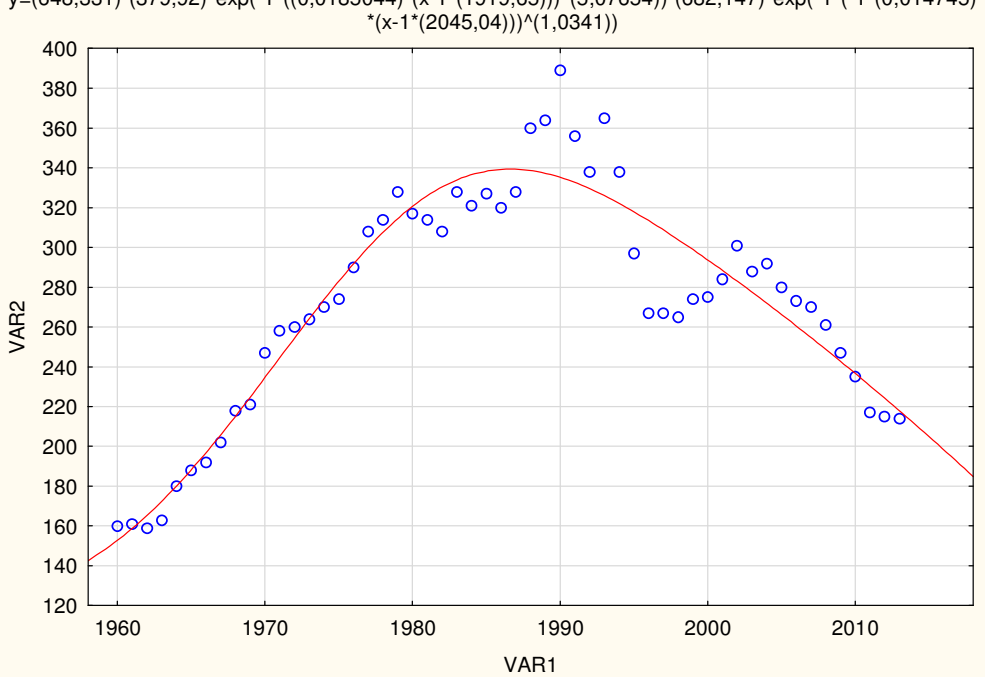

11. ábra. 11Tojásdb

\begin{tabular}{|c|c|c|c|c|c|c|c|c|c|}
\hline \multirow[b]{2}{*}{$\mathrm{N}=54$} & \multicolumn{9}{|c|}{ 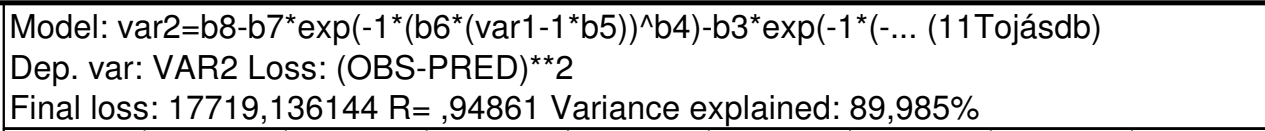 } \\
\hline & b8 & b7 & b6 & b5 & b4 & b3 & b2 & b1 & b0 \\
\hline Estimate & 648,33 & 379,92 & 0,0185 & 1919,6: & 5,0765 & 682,14 & 0,0147 & 2045,0 & 1,0341 \\
\hline
\end{tabular}

12. táblázat. 11Tojásdb

Model: Ivar2=b8-b7* $\exp \left(-1^{*}\left(\mathrm{~b} 6^{*}\left(\operatorname{var} 1-1^{*} \mathrm{~b} 5\right)\right)^{\wedge} \mathrm{b} 4\right)-\mathrm{b} 3^{*} \exp \left(-1^{*}\left(-1^{*} \mathrm{~b} 2^{*}\left(\operatorname{var} 1-1^{*} \mathrm{~b} 1\right)\right)^{\wedge} \mathrm{b} 0\right)$

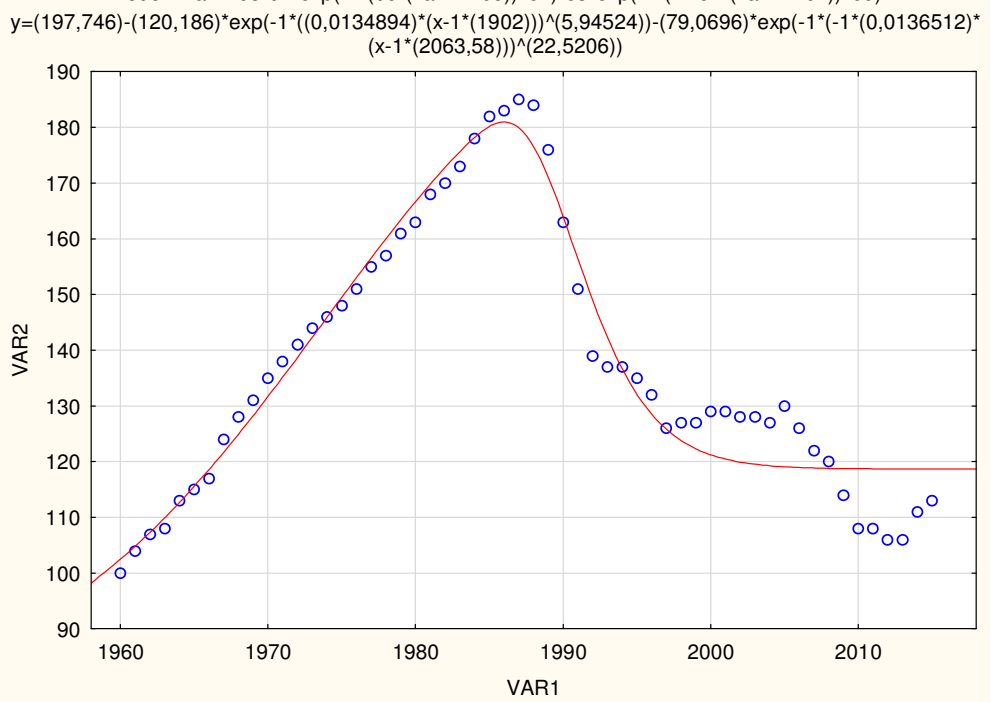

12. ábra. 12Utasszám

\begin{tabular}{|c|c|c|c|c|c|c|c|c|c|}
\hline \multirow[b]{2}{*}{$\mathrm{N}=56$} & \multicolumn{9}{|c|}{$\begin{array}{l}\text { Model: var2 }=\mathrm{b} 8-\mathrm{b} 7^{*} \exp \left(-1^{*}\left(\mathrm{~b} 6^{\star}\left(\operatorname{var} 1-1^{*} \mathrm{~b} 5\right)\right)^{\wedge} \mathrm{b} 4\right)-\mathrm{b} 3^{*} \exp \left(-1^{*}(-\ldots(12 \text { Utasszám) }\right. \\
\text { Dep. var: VAR2 Loss: }(\text { OBS-PRED })^{\star *} 2 \\
\text { Final loss: } 1620,1700191 \mathrm{R}=, 97375 \text { Variance explained: } 94,820 \%\end{array}$} \\
\hline & b8 & b7 & b6 & b5 & $\mathrm{b} 4$ & b3 & b2 & b1 & b0 \\
\hline Estimate & $197,74 !$ & $120,18 t$ & $0,0134\{$ & 1901,95 & 5,9452 & $79,069 !$ & 0,0136 ? & $2063,5\}$ & 22,520 \\
\hline
\end{tabular}

13. táblázat. 12Utasszám 


\subsection{Elemzés, értékelés}

Az 56 év alatti változás modellértékeinek összefoglalása.

A felsorolt megnevezett adatsorokra a megadott függvény regressziós alkalmazásával nyert paraméterekből kapott értékek az alábbiakban olvashatók az értékelő táblázatban:

\begin{tabular}{||l||c|c|c|c|c|c||}
\hline \multicolumn{1}{|c|}{ Adatsor } & $\begin{array}{c}\text { Pontosság } \\
\text { R értékei }\end{array}$ & $\begin{array}{c}\text { Ért. tart. } \\
\text { b5<var1 }<\text { b1 }\end{array}$ & $\begin{array}{c}\text { Érték var2 } \\
\text { előjel }\end{array}$ & $\begin{array}{c}\text { Jelző } \\
\text { kitevő }\end{array}$ & $\begin{array}{c}\text { Jelző } \\
\text { szorzó }\end{array}$ & $\begin{array}{c}\text { Elöre jelzési } \\
\text { mód }\end{array}$ \\
\hline \hline 1. Burgonya & 0,9804 & $1940-2014$ & + & $\mathrm{b} 0>2$ & $* * \mathrm{~b} 7<0$ & kizárt \\
\hline 2. Csalpot & 0,9868 & $1890-2088$ & + & $\mathrm{b} 0>2$ & $\mathrm{~b} 7>0$ & lehetséges \\
\hline 3. Dolgozó & 0,9778 & $1958-2016$ & + & $\mathrm{b} 0>2$ & $\mathrm{~b} 7>0$ & lehetséges \\
\hline 4. Földgáz & 0,9914 & $1950-2054$ & $*_{-}+$ & $\mathrm{b} 0>2$ & $\mathrm{~b} 7>0$ & lehetséges \\
\hline 5. Kórágyak & 0,9788 & $1890-2065$ & + & $\mathrm{b} 0>2$ & $\mathrm{~b} 7>0$ & lehetséges \\
\hline 6. Nyugdíjas & 0,9958 & $1920-2074$ & +- & $* * \mathrm{~b} 0<2$ & $\mathrm{~b} 7>0$ & kizárt \\
\hline 7. Ovodások & 0,9888 & $1922-2018$ & + & $\mathrm{b} 0>2$ & $\mathrm{~b} 7>0$ & lehetséges \\
\hline 8. Pamutsz & 0,9917 & $1945-2029$ & + & $\mathrm{b} 0>2$ & $\mathrm{~b} 7>0$ & lehetséges \\
\hline 9. Sör & 0,9747 & $1910-2049$ & + & $\mathrm{b} 0>2$ & $\mathrm{~b} 7>0$ & lehetséges \\
\hline 10. Telhivás & 0,9972 & $1940-2022$ & + & $\mathrm{b} 0>2$ & $\mathrm{~b} 7>0$ & lehetséges \\
\hline 11. Tojásdb & 0,9486 & $1919-2045$ & +- & $* * \mathrm{~b} 0<2$ & $\mathrm{~b} 7>0$ & kizárt \\
\hline 12. Utasszám & 0,9738 & $1901-2063$ & + & $\mathrm{b} 0>2$ & $\mathrm{~b} 7>0$ & lehetséges \\
\hline
\end{tabular}

14. táblázat. Értékelő

A táblázatban csillaggal jelölt információk az alábbiak szerint értékelendők:

* az előrejelzés lehetséges, az értelmezési tartomány alsó határán a nullához balról tartó értékek jelennek meg,

** az értékek arra utalnak, hogy az előrejelzés lehetősége kizárt.

A 15. táblázatban az illesztett modell és az adatsor összevetése alapján levonható jellemzők találhatók.

\begin{tabular}{||l||l|l|c|c|c|l||}
\hline \multicolumn{1}{||c|}{ Folyamat } & $\begin{array}{c}\text { Növekedés } \\
\text { időszaka }\end{array}$ & $\begin{array}{c}\text { Max.,Min., } \\
\text { Törés } \\
\text { Időpontja }\end{array}$ & $\begin{array}{c}\text { Csökkenés } \\
\text { időszaka }\end{array}$ & $\begin{array}{c}\text { Bizonytalan } \\
\text { változás } \\
\text { időszaka }\end{array}$ & $\begin{array}{c}\text { Fő változás } \\
\text { időpontja }\end{array}$ & $\begin{array}{c}\text { Kiegyen- } \\
\text { súlyozódás }\end{array}$ \\
\hline \hline 1. Burgonya & $1986-2001$ & $1986(\min )$ & $1960-1986$ & $2001-2015$ & 1986 & bizonytalan \\
\hline 2. Csalpot & $1960-1991$ & $1991(\max )$ & $1991-1997$ & $1997-2015$ & 1991 & várható \\
\hline 3. Dolgozó & $1960-1977$ & $1977(\max )$ & $1977-1998$ & $1998-2015$ & 1977 & megjelent \\
\hline 4. Földgáz & $1960-1986$ & $1986(\max )$ & $1986-2015$ & --- & 1986 & várható \\
\hline 5. Kórágyak & $1960-1989$ & $1989(\max )$ & $1989-2015$ & --- & 1989 & várható \\
\hline 6. Nyugdíjas & $1960-1999$ & $1999(\max )$ & $1999-2015$ & --- & 1999 & bizonytalan \\
\hline 7. Ovodások & $1960-1981$ & $1981(\max )$ & $1981-2015$ & --- & 1981 & várható \\
\hline 8. Pamutsz & $1960-1977$ & $1977(\max )$ & $1977-2015$ & --- & 1977 & várható \\
\hline 9. Sör & $1960-1990$ & $1990(\max )$ & $1990-1999$ & $1999-2015$ & 1990 & bizonytalan \\
\hline 10. Telhivás & $1960-1999$ & $1999(\max )$ & $1999-2015$ & --- & 1999 & bizonytalan \\
\hline 11. Tojásdb & $1960-1990$ & $1990(\max )$ & $1990-2015$ & --- & 1990 & bizonytalan \\
\hline 12. Utasszám & $1960-1987$ & $1987(\max )$ & $1987-1997$ & $1997-2015$ & 1987 & bizonytalan \\
\hline \hline
\end{tabular}

15. táblázat. Változások

Az 56 év alatti változások jellegét meghatározó táblázatból levonható következtetések, valamint a folyamat lefutási karakterét bemutató értékek ismeretében a következők állapíthatók meg:

a.) A minden egyes folyamatot leíró függvénygörbe egy szélsőértékkel, maximummal rendelkezik, az 1.) eset kivételével. 
b.) A folyamat szélsőértéke eleget tesz az elsőderivált előjel váltásának, az érintő irány változása jól látható. Kivételt képez a 3.) és 8.) jelü eset.

c.) A 2015-ös év után a vizsgált tizenkét folyamatból 6 esetben kiegyensúlyozódás várható.

d.) A folyamatok kedvezőtlen alakulásának időtartama változó.

e.) A változást az 1977-1999 éves időszak jelzi. A 12 esetből azonban 8 esetben ez az 1981-1991. időintervallumra esik.

\section{3. Összefoglaló}

Mivel a vizsgált 56 év 12 különböző változást leíró statisztikai adatsorának regressziós elemzéséhez ugyanazon szerkesztett, összetett, nagy rugalmasságú függvény használatára került sor, így a folyamatok azonos rendszerü elemzésének adott volt a lehetősége. Ennek alapján az előbbiekben felsorolt öt megállapítás a vizsgált időintervallumon alapvető jellegü, és jól mutatja a vizsgált adatsorok változását, annak jellegét és következményeit. Természetesen szükségesnek mutatkozik a 2015-ös évtől kezdett alapos adatgyüjtés, annak érdekében, hogy megállapítható legyen az említett kiegyensúlyozódás illetve az adott esetben pozitív irányú fejlődés.

\section{Irodalomjegyzék}

[1] Csanády V., Horváth-Szováti E., Szalay L., Alkalmazott statisztika, Sopron, Nyugat-Magyarországi Egyetem Kiadó, 2013.

[2] Központi Statisztikai Hivatal honlapja, https://www.ksh.hu/stadat. 